3. Абакуменко Е. В. Вопросы реализации принципа диспозитивности в праве. Актуальні проблеми держави і права. Одеса, 2011. Вип. 57. C. 85-91.

4. Романюк Я. М. Правова природа диспозитивних норм цивільного права України. Вісник Національної академії правових наук Украӥни. 2016. № 4 (87). С. 138-151.

5. Господарський процесуальний кодекс України: Закон України від 6 листопада 1991 року № 1798-XII в редакції від 5 липня 2021року. URL: https://zakon.rada.gov.ua/laws/show/1798-12\#Text.

\title{
DOI https://doi.org/10.30525/978-9934-26-179-4-20
}

\section{КОНЦЕПЦІЯ СТАЛИХ ПУБЛІЧНИХ ЗАКУПІВЕЛЬ В УКРАЇНІ В УМОВАХ СВРОІНТЕГРАЦІЇ}

\author{
Шевчук Л. М. \\ кандидат юридичних наук, \\ доцент кафедри иивільно-правових дисциплін \\ Волинський національний університет імені Лесі Украӥнки \\ м. Луцькк, Украӥна
}

Беззаперечно знаковою подією, яка ознаменувала перехід людства на якісно новий щабель свого розвитку, стало прийняття 25.09.2015 Резолюції Генеральної Асамблеї ООН «Перетворення нашого світу: Порядок денний у сфері сталого розвитку до 2030 року», якою оголошено новий план дій, орієнтований на виведення світу на траєкторію сталого та життєстійкого розвитку, що включає 17 цілей сталого розвитку і 169 завдань [1].

Підтримуючи проголошені ООН глобальні цілі сталого розвитку, 3 метою забезпечення національних інтересів України щодо сталого розвитку економіки, громадянського суспільства i держави для досягнення зростання рівня та якості життя населення, додержання конституційних прав i свобод людини i громадянина, Указом Президента України «Про Цілі сталого розвитку України на період до 2030 року» від 30.09.2019 № 722/2019 визначено необхідність забезпечення дотримання усіх сімнадцяти цілей [2]. Окремо в цьому акті наголошено на тому, що цілі сталого розвитку держави на період до 2030 року є орієнтирами для розроблення проектів прогнозних i 
програмних документів, проектів нормативно-правових актів 3 метою забезпечення збалансованості економічного, соціального та екологічного вимірів сталого розвитку України [2].

Таким чином, усі три складові сталого розвитку - економічна, соціальна й екологічна - у їх нерозривному зв'язку та балансі стають визначальними при регламентації ключових сфер державного i суспільного життя як на глобальному (світовому), так і на національному (державному) рівнях. 3 урахуванням того, що в Україні забезпечення потреб держави, територіальних громад та об'єднаних територіальних громад здійснюється із застосуванням публічних закупівель, цілком обгрунтовано можна стверджувати, що цілі сталого розвитку повною мірою повинні враховуватися й при регулюванні закупівельної сфери в країні.

Радикальні зміни у вітчизняному законодавстві 3 цих питань і зміщення акцентів 3 суто економічного підходу до врахування соціальних та екологічних факторів при організації та здійсненні закупівель в нашій державі відбулися у зв'язку з прийняттям 19.09.2019 Закону України «Про внесення змін до Закону України «Про публічні закупівлі» та деяких інших законодавчих актів України щодо вдосконалення публічних закупівель» № 114-IX [3], яким Закон України «Про публічні закупівлі» від 25.12.2015 № 922-VIII [4] (далі Закон № 922-VIII) викладено в новій редакції. Такі новели в національній нормативно-правовій базі значною мірою були зумовлені необхідністю адаптувати законодавство України acquis Свропейського Союзу на виконання Угоди про асоціацію між Україною, з однієї сторони, та Європейським Союзом, Свропейським співтовариством 3 атомної енергії і їхніми державами-членами, з іншої сторони [5], як це визначено в преамбулі оновленого Закону № 922-VIII.

Саме на євроінтеграційному векторі розвитку України та меті досягнення державою цілей сталого розвитку в закупівельній сфері наголошено і в Стратегії реформування системи публічних закупівель («дорожній карті») (далі- Дорожня карта), схваленої розпорядженням КМ України від 24.02.2016 № 175-р: «Реформа у сфері публічних закупівель пов'язана із політичними, правовими, соціальними, фінансовими, інституційними, етичними та технологічними завданнями, розв'язання яких сприятиме сталому соціально-економічному розвитку держави, конкурентоспроможності економіки та динамічній інтеграції України в міжнародні ринки, зокрема в спільний ринок ЄС» [6].

В числі актів СС, у відповідність до яких передбачено приведення національного закупівельного законодавства, у Дорожній карті названо Директиву 2014/24/СС від 26 лютого 2014 року про державні закупівлі, 
якою скасовується Директива 2004/18/СС [7] і Директиву 2014/25/СС Європейського Парламенту та Ради від 26 лютого 2014 року щодо здійснення закупівлі організаціями, що працюють у водному, енергетичному, транспортному та поштовому секторах, якою скасовується Директива 2004/17/СС [8]. Низка положень обох із названих директив знайшли закріплення у чинній редакції Закону № 922-VIII, зокрема в частині посилення екологічної і соціальної складових при організації та здійсненні закупівель.

Таким чином, сьогодні у профільному вітчизняному акті з питань закупівель - Законі № 922-VIII - спостерігаємо поєднання економічного, соціального та екологічного підходу до закупівель. Безумовно, визначальним у здійсненні публічних закупівель в Україні залишається закріплений у п. 2 ч. 1 ст. 5 цього акту принцип максимальної економії, ефективності та пропорційності (економічна складова). Однак поряд 3 економічним підходом у Законі №922-VIII передбачений досить широкий спектр можливостей для врахування екологічної складової: 1) права замовника при визначенні технічних та якісних характеристик предмета закупівлі у тендерній документації встановлювати екологічні характеристики товарів, робіт і послуг (п. 3 ч. 2 ст. 22, ч. 3 ст. 23) [4] та визначати вимоги щодо підтвердження відповідності таким характеристикам (ч. 5 ст. 23) [4]; 2) право замовника застосовувати у якості критерію оцінки тендерних пропозицій (пропозицій) вартість життєвого циклу, що дозволяє враховувати у його складі витрати екологічного характеру (ч. 3 і ч. 4 ст. 29) [4]; 3) право замовника при встановленні такого критерію оцінки як ціна використовувати його самостійно або разом з іншими критеріями оцінки, у тому числі такими як застосування заходів охорони навколишнього середовища, які пов'язані із предметом закупівлі (п. 3 ч. 3 ст. 29) [4].

Соціальна ж складова частково реалізовується лише в нормах окремих статей закону, які містять пряму вказівку на досягнення соціальних результатів, наприклад: «Придбання замовником товарів, робіт і послуг, вартість яких дорівнює або перевищує 50 тисяч гривень та $\epsilon$ меншою за вартість, що встановлена у пунктах 1 та 2 частини першої цієї статті, здійснюється без застосування порядку проведення спрощених закупівель, встановленого цим Законом, у разі якщо закупівля товарів і послуг здійснюється у підприємства або організації, що засноване(а) громадською організацією осіб 3 інвалідністю та отримало(а) дозвіл на право користування пільгами з оподаткування відповідно до законодавства» (п. 8 ч. 7 ст. 3) та «У разі якщо предмет закупівлі в подальшому буде використовуватися фізичними особами, технічні специфікації повинні складатися з урахуванням потреб осіб 82 
з інвалідністю або проектувальних вимог для врахування потреб усіх категорій користувачів» (ч. 2 ст. 23) [4].

Підсумовуючи викладене, можна констатувати, що нині Україна перебуває на шляху переходу до сталих публічних закупівель, тобто таких закупівель товарів, робіт і послуг для забезпечення потреб держави, територіальних громад та об'єднаних територіальних громад, які орієнтовані на досягнення мети дотримання балансу їх трьох складових: економічної, соціальної та екологічної. В сучасних умовах державою створене відповідне правове підгрунтя для перспективної реалізації концепції сталих публічних закупівель, однак подальше вітчизняне нормативне регулювання закупівельної діяльності повинне здійснюватися з урахуванням необхідності розширення та посилення норм екологічного й соціального характеру відповідно до світових $\mathrm{i}$ європейських підходів у цій сфері.

\section{Література:}

1. Перетворення нашого світу: Порядок денний у сфері сталого розвитку до 2030 року : Резолюція Генеральної Асамблеї ООН від 25.09.2015 № 70/1. URL: https://undocs.org/en/A/RES/70/1 (дата звернення: 23.12.2021).

2. Про Цілі сталого розвитку України на період до 2030 року : Указ Президента України від 30.09.2019 № 722/2019. URL: https://zakon.rada.gov.ua/laws/show/722/2019\#Text (дата звернення: 23.12.2021).

3. Про внесення змін до Закону України «Про публічні закупівлі» та деяких інших законодавчих актів України щодо вдосконалення публічних закупівель : Закон України від 19.09.2019 № 114-IX. URL: https://zakon.rada.gov.ua/laws/show/114-20\#Text (дата звернення: 23.12.2021).

4. Про публічні закупівлі : Закон України від 25.12.2015 № 922-VIII. URL: https://zakon.rada.gov.ua/laws/show/922-19\#Text (дата звернення: 23.12.2021).

5. Угода про асоціацію між Україною, 3 однієї сторони, та Європейським Союзом, Європейським співтовариством 3 атомної енергії і їхніми державами-членами, 3 іншої сторони : Угода від 27.06.2014. URL: https://zakon.rada.gov.ua/laws/show/984_011\#Text (дата звернення: 23.12.2021).

6. Стратегія реформування системи публічних закупівель («дорожня карта»), схвалена розпорядженням Кабінету Міністрів України від 24.02.2016 № 175-p. URL: https://zakon.rada.gov.ua/laws/show/175-2016\%D1\%80\#Техt (дата звернення: 23.12.2021). 
7. Директива 2014/24/СС Свропейського парламенту і Ради СС від 26 лютого 2014 року про державні закупівлі та скасування Директиви 2004/18/EC. Збірник Директив СС з питань державних закупівель. 2015. URL: https://dn.gov.ua/storage/app/sites/1/zakupivli/dodatok-31dyrektyvyyes-po-zakupivlyah-1.pdf (дата звернення: 23.12.2021).

8. Директива 2014/25/СС Європейського Парламенту та Ради від 26 лютого 2014 року щодо здійснення закупівлі організаціями, що працюють у водному, енергетичному, транспортному та поштовому секторах, якою скасовується Директива 2004/17/СС. Збірник Директив ЄC 3 питань державних закупівель. 2015. URL: https://dn.gov.ua/ storage/app/sites/1/zakupivli/dodatok-31dyrektyvy-yes-po-zakupivlyah-1. pdf (дата звернення: 23.12.2021). 